\title{
THE USE OF RAP MUSIC TO IMPROVE STUDENTS' VOCABULARY MASTERY AT THE FIRST GRADE STUDENTS OF SMPN 2 PAPALANG MAMUJU REGENCY
}

\author{
Dyan Elviyana Savitri \\ Indah Fadhilah Rahman \\ English Education Department of UIN Alauddin Makassar \\ Elviyana@gmail.com \\ Fadhilah_iin30@gmail.com
}

\begin{abstract}
The objective of this study was to to find out the extent of Rap Music improves the students' vocabulary mastery. This study was focused on improving the students' vocabulary in irregular verbs mastery. The research design applied in this study was a Quasi Experimental Design exactly Non-Equivalent Control Group Design covering 6 meetings for each classes (Experimental class and Controlled Class). The instruments used was test. Further, the data analysis techniques involved in this study was quantitative analysis. The findings of this study showed that first grade students' of SMPN 2 Papalang vocabulary mastery (irregular verbs) improved by the Rap Music by the increase of mean score of Experimental class that was 8.68 in the pre test and 48.89 in the post-test. It was also proved by the result of the statistical analysis indicated that the t-test values of the Rap Music in the post-test was 6.74 higher than t-table 2.021 (6.74 > 2.021). Based on the fact, $\mathrm{H}_{1}$ was accepted and $\mathrm{H}_{0}$ was rejected, the researcher concluded that Rap Music was effective to improve students' vocabulary mastery at the first grade students of SMPN 2 Papalang, Mamuju Regency.
\end{abstract}

Keywords: Rap Music, irregular verbs, students' vocabulary mastery

\section{INTRODUCTION}

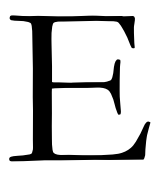

nglish has been introduced from elementary school to university, even some kindergartens in big cities have introduced it as one of the subjects. But, not all the students in Indonesia can get the same opportunity to learn English in early ages. As an example is in the researcher's hometown Mamuju regency, students over there only get the English subject in Junior High School. Teaching English in junior high school specifically for students who acquire English as their first foreign language is not an easy job. Surely, they will faced many problems, and one of the most serious problem is lack of vocabulary, while vocabulary is very important to master by students because vocabulary is needed to improve the four English skills: listening, speaking, reading, and writing. Because they are lack of vocabulary the consequent is that they will be difficult to understand the sentences in the book while the book is the only teaching media at SMPN 2 Papalang. They can't understand the sentences or texts in the book because there are the changes of words with the same meaning. Sometimes they can not distinguish among eat, ate, and eaten, while the words have the same meaning The change of words becomes the main problem that 
Dyan Elviyana Savitri \& Indah Fadhilah Rahman, The Use of Rap Music to Improve Students...

make the students confused to learn English. It is called the irregular verb. Irregular verb is very important to mastered by the students or young learners in the beginning level because they will be unable to make present tense, past tense, past participle, descriptive text, recount text, and so on in the next grade if the students do not know the irregularverb first.

Based on the problems above, the researcher wants to take Rap Music as a teaching techniques that can make the students motivated to learn irregular verb and make the learning English vocabulary more interesting and enjoyable. Burke (2014) agreed that through music, will definitely enhance students language comprehension. English music improves students' listening skill and increases students' vocabulary, music even helps students' pronunciation. According to Abbott's (2002) theory, repetition can help build language and fluency, and then rap songs can definitely help stimulate second language learning because of its repetitive format.

The researcher decides to take Rap Music as a technique because Rap Music has strong rhytm and repetition, Medina (2002) agreed that we have good memory with music because all those repetitive words and rhythm stay in our head even after the English lesson. When we add rhythm and melody into language, it will help us to transfer words into long-term memory. Medina concluded that it is impossible to acquire language without memory.So, through this research, the researcher expects that students who just learn English as their first foreign language can be mastering the irregular verbs without any obstacles.

Furthermore, the research problem of this research was "to what extent does RapMusic improves the students' vocabulary mastery at the first grade students of SMPN 2 Papalang Mamuju regency?". Then, the research objective was to find out the extent of Rap Music improves the students' vocabulary mastery. In addition, this research was beneficial practically in the context for the students (they can improve their vocabulary mastery), the teachers (they can implement Rap Music to solve their students' vocabulary problems), and the further researcher (they can use the finding of this study as one of their references). Finally, this study was focused on improving the students' vocabulary in mastering irregular verbs. The Rap Music that the researcher used was based on Stick Stuck Stuck which is made by Jason R. Levine or usually called Fluency MC. Stick Stuck Stuck is a name of song that consists of irregular verbs which is combined with Rap Music that can help English learners.

\section{LITERATURE REVIEW}

A number of studies had been conducted in order to investigate the effectiveness of Rap Music. First, preview finding was came from Segal (2014) in her thesis entitled: Teaching English as a Second Language through Rap Music: A Curriculum for Secondary Students. From the objective of her research, she stated that by using original Rap Music to present lessons, the curriculum bypasses the traditional reading and writing methods, and instead presents content material through a popular form of music that is relevant to youth. Through rap, this 
curriculum provides a discourse approach to second language learning. This project show rationale that teaching language through the medium of Rap Music is highly effective and in line with sound linguistic and educational theory.

Furthermore, Ječmínková (2009) in her thesis entitled: Music and Songs in Adult ESL Teaching. The aim of this thesis was to provide an insight into the area of adult language teaching with the focus on listening comprehension. Music and songs are materials that she means in her thesis. Then she took a practical example of some rap activities that can be used in an adult language classroom, a lesson plan practicing English pronunciation through rap was suggested at the end of her thesis. The result was the channel of Rap Music helps students of English to experiment and practice the word and sentence stress and positively affect their communicating skills.

Based on the explanation above, the researcher concludes that there are various ways to develop English comprehension through RapMusic. But for this research, researcher takes vocabulary, therefore, to improve students' vocabulary mastery at the first grade students of SMPN 2 PAPALANG Mamuju regency.

This section presented the pertinent ideas about the definition of vocabulary, types of vocabulary, the importance of vocabulary, teaching vocabulary, and Rap Music.

1. The definition of vocabulary

Oxford (2008: 495), vocabulary is all the words that a person knows or uses: all the words in a language, or list of words with their meanings, especially in a book for learning a foreign language.

2. Types of vocabulary

Schall in Zuhdy (2011: 10) classified vocabulary into three types, namely:

a) Active vocabulary, the words are customarily used in speaking.

b) Reserve vocabulary, the words we know but we are rarely used them in ordinary speech. We use them in writing letter and searching for synonym.

c) Passive vocabulary, the words are recognize vaguely but we are sure of the meaning never use them is either speech or writing, we just know them because we see them before.

3. The Importance of vocabulary

Vocabulary is the body of words that make up the language. Without a good working knowledge of words and their meanings, both written and verbal communication will be muddied or poorly understood. No one can communicate in any meaningful way without vocabulary. Lack of vocabulary will keep the learners unable to express their thoughts and feelings while having a number vocabulary gives them right words to use in the right time. It will enable them to communicate clearly and speak with great precision with others (Harisman, 2014: 9). 
4. Teaching Vocabulary

To be able to teach as effectively as possible, it is important to know, how words are remember and stored in students' minds and how long term memory is organized (Thornbury: 2004). Moreover, students need to acquire the ability to store the information for as long as possible.

Thornbury (2004) summarized a research into memory, which suggests principles supporting the process of permanent or long - term remembering. There are some techniques to follow to make teaching vocabulary as effective as possible:
a) Repetition
b) Motivation
c) Picture
d) Music

\section{RESEARCH METHOD}

The design of the research was Quasi Experimental Design, exactly Nonequivalent Control Group Design. In this method, there were two classes, which were Experimental class and Controlled class, then the researcher used pre-test and post-test design in both Experimental and Controlled class. Thus, the researcher wanted to know whether using Rap Music in teaching vocabulary give the significant effect to improve the students' vocabulary mastery or not. This can be presented as follows:

Figure 3.1 Experimental Design

\begin{tabular}{|llll|}
\hline $\mathrm{E}$ & $\mathrm{O}_{1}$ & $\mathrm{X}$ & $\mathrm{O}_{2}$ \\
\hline $\mathrm{C}$ & $\mathrm{O}_{3}$ & & $\mathrm{O}_{4}$ \\
\hline
\end{tabular}

Explanation:

E : Experimental class

C : Controlled class

$\mathrm{O}_{1}:$ Pre-test (in Experimental class)

$\mathrm{O}_{3}$ : Pre-test (in Controlled class)

$\mathrm{X}$ : Treatment for Experimental class by using Rap Music

$\mathrm{O}_{2}$ : Post-test (in Experimental class)

$\mathrm{O}_{4}$ : Post-test (in Controlled class)

(Sugiyono, 2015: 116)

Based on the previous table, there were two classes which were divided into Experimental class (E) and Controlled class (C). Both of them did the pre-test (O1 and O3). 
The pretest was given in order to get to know students' prior knowledge before the treatment.

Next, the treatment $(\mathrm{X})$ was applied to the Experimental class, the students of Experimental class was taught by Rap Music.

Then after giving the treatment the resercher gave post-test. Post-test (O2 and O4) was given to both classes. Post-test wass applied in order to know students' achievement of the two classes. The score of both classes were compared to see the improvement.

The population of this research was all of the students in the first grade of SMPN 2 Papalang, Mamuju Regency 2016-2017 that consisted of two classes and each classes consisted of 19 students. So the total number of population were 38 students. Because there were only 2 classes in first grade of SMPN 2 Papalang, so the researcher took them as population and as sample all at once. The classes of the first grade of SMPN 2 Papalang are VII 1 which has 19 students and VII 2 has 19 students. The researcher took VII 1 as a Controlled class while VII 2 as an Experimental class.

To obtain the data, test of vocabulary applied, namely pre-test and post-test. The test used to find out whether the students' vocabulary mastery improved or not. The function of pre-test was to know how far the vocabulary mastery of the students before applying Rap Music and the function of post-test was to know the improvement of students' vocabulary mastery after applying Rap Music. The test consisted of fill in the blank, and crossword. The test consisted of 30 items of irregular verbs. In the Pre-test, the first model of fill in the blank consisted of 15 items, and the second model of fill in the blank consisted of 5 items, while crossword consisted of 10 items. In the Post-test, the first model of fill in the blank consisted of 12 items, and the second model of fill in the blank consisted of 8 items, while crossword consisted of 10 items.

In collecting data, the researcher brought 3 (three) activities as follows:

1. Administering the pre-test

In administering this pre-test, the researcher gave 30 number of irregular verbs test. It was carried out on Monday, $25^{\text {th }}$ July 2016 in the Controlled class and on Tuesday, $26^{\text {th }}$ July 2016 in the Experimental class. The time was given 60 minutes. After giving the pre-test, each meeting ran for 90 minutes for leading the treatment.

2. Administering the treatment

In administering this treatment, the researcher took six meetings, they were carried out on Friday, 29 ${ }^{\text {th }}$ July 2016, Tuesday $2^{\text {nd }}$ August 2016, Friday $5^{\text {th }}$ August 2016, Tuesday $9^{\text {th }}$ August 2016, Friday $12^{\text {th }}$ August 2016, Tuesday $16^{\text {th }}$ August 2016.

3. Administering the post-test

In administering the post-test, the researcher gave 30 number of irregular verbs test. It was carried out on Thursday, $18^{\text {th }} 2016$ in the Controlled class and on Friday, $19^{\text {th }}$ August 
Dyan Elviyana Savitri \& Indah Fadhilah Rahman, The Use of Rap Music to Improve Students...

2016 in the Experimental class. The time was given 60 minutes.

The data collected through the test by using inferential statistic percentage score is also used to know the students' ability in vocabulary mastery. The formula used to test the hypothesis was t-test with the level of significance 0,05 (95\%). The steps under taken in quantitative analysis employing the next page formulas:

Firstly, the formula that was used to calculate the students' score per person as follows:

$$
\mathrm{S}=\frac{\sum \mathrm{R}}{\mathrm{n}} \times 100
$$

Where:

$S$ : Score

$\sum \mathrm{R}$ : The sum of right answers

$\mathrm{N}$ : The total number of items

(Adapted from Purwanto, 2009: 65)

Secondly, the criteria that were used to classify the score answer of the students pretest and post-test:

\begin{tabular}{|c|c|c|}
\hline No. & Score & Classification \\
\hline 1 & $96-100$ & Excellent \\
\hline 2 & $86-95$ & Very good \\
\hline 3 & $76-85$ & Good \\
\hline 4 & $66-75$ & Fairly Good \\
\hline 5 & $56-65$ & Fair \\
\hline 6 & $36-55$ & Fairly Poor \\
\hline 7 & $0-35$ & Poor \\
\hline
\end{tabular}

(Depdikbud in Sukirman 2010:36)

Thirdly, the formula that was used to calculate the percentage of the students' score as below:

$$
P=\frac{\mathbf{F}}{\mathrm{N}} \times 100
$$

Where:

$\mathrm{P}$ : percentage

$\mathrm{F} \quad$ : frequency

$\mathrm{N}$ : the total number of students

(Depdikbud in Nur 2011)

Next, the formula that was used to calculate the mean score of the students' answer as follows:

$$
\bar{x}=\frac{\sum \mathrm{x}}{\mathrm{N}}
$$

Where:

$\bar{x}:$ mean score 
$\sum x:$ sum of all scores

$\mathrm{N}:$ total number of the respondent

(Gay, 2006: 320)

After that, the formula that was used to know whether the mean score was exceptional or not as follows:

$$
S D=\sqrt{\frac{S S}{N}, \text { where } \mathrm{SS}=\sum \mathrm{X}^{2}-\frac{\left(\sum X\right)^{2}}{N 1}}
$$

(Gay, 2006: 321).

Where:

SD : standard deviation

SS : the sum of square

$\mathrm{N}$ : total number of the subjects

$\sum X^{2}$ : the sum of all square: each score is squared and all the squares are added up

$\left(\sum X\right)^{2}$ : the square of the sum: all the scores are added up and the sum is square, total.

Then, the formula that was used to know the significant difference between the result of the Experimental class and the Controlled class by calculating the value of the test, as follows:

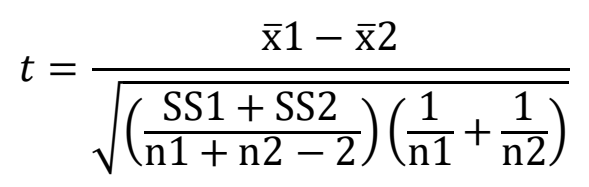

(Gay, 2006: 349)

Where:

$$
\begin{array}{cll}
\mathrm{t}: & \text { test of significance } \\
\overline{\mathrm{x}}_{1}: & \text { mean score of experimental group } \\
\overline{\mathrm{X}}_{2}: & \text { mean score of controlled group } \\
\mathrm{SS}_{1}: & \text { sum square of experimental group } \\
\mathrm{SS}_{2}: & \text { sum square of controlled group } \\
\mathrm{n}_{1}: & \text { number of students of experimental group } \\
\mathrm{n}_{2}: & \text { number of students of cotrolled group } \\
2: & \text { the number of class involved } \\
1: & \text { constant number }
\end{array}
$$

Then the last, the result of the $t$ test will be compared with $t$ table to see if there is a significant difference between the Experimental class and Controlled class on the other hand, the experiment is effective or not. 
Dyan Elviyana Savitri \& Indah Fadhilah Rahman, The Use of Rap Music to Improve Students...

T table $\leq \mathrm{t}$ test $=$ Effective

$\mathrm{T}$ table $\geq \mathrm{t}$ test $=$ Not effective

(Gay, 2006: 346)

\section{FINDINGS AND DISCUSSION}

\section{A. Findings}

The findings of the research were based on the results of the data analysis. The data analysis was used to collect data. The vocabulary test consists of pre test and post test. The pre test was given to find out the initial students' vocabulary before pres enting Rap Music, and the post test was given to find out the improvement of the students' vocabulary after giving the treatment.

\section{Result of Students' Pre Test in Experimental and Controlled Class}

The distribution of frequency and percentage of final score of students' vocabulary at the first grade at SMPN 2 Papalang, Mamuju Regency in pre test of Experimental class and Controlled class are shown in the next page tables.

Table 4.1 The distribution of frequency and percentage score of Experimental class score in pre-test

\begin{tabular}{|c|c|c|c|c|}
\hline No. & Classification & Score & Frequency & Percentage \\
\hline 1. & Excellent & $95-100$ & 0 & $0 \%$ \\
\hline 2. & Very Good & $85-94$ & 0 & $0 \%$ \\
\hline 3 & Good & $75-84$ & 0 & $0 \%$ \\
\hline 4. & Fairly Good & $65-74$ & 0 & $0 \%$ \\
\hline 5. & Fair & $55-64$ & 0 & $0 \%$ \\
\hline 6. & Fairly Poor & $45-54$ & 0 & $0 \%$ \\
\hline 7. & Poor & $0-44$ & 19 & $100 \%$ \\
\hline \multicolumn{3}{|c|}{ TOTAL } & 19 & $100 \%$ \\
\hline
\end{tabular}

Table 4.1 above shows the rate percentage of score of Experimental class in pre-test from 19 students, none of the students got Fairly poor until Excellent score and all students got Poor score $(100 \%)$.

Table 4.2 The distribution of frequency and percentage score of Controlled class score in pre-test

\begin{tabular}{|c|c|c|c|c|}
\hline No. & Classification & Score & Frequency & Percentage \\
\hline 1. & Excellent & $96-100$ & 0 & $0 \%$ \\
\hline 2. & Very Good & $86-95$ & 0 & $0 \%$ \\
\hline 3 & Good & $76-85$ & 0 & $0 \%$ \\
\hline 4. & Fairly Good & $66-75$ & 0 & $0 \%$ \\
\hline 5. & Fair & $56-65$ & 0 & $0 \%$ \\
\hline 6. & Fairly Poor & $36-55$ & 1 & $5 \%$ \\
\hline 7. & Poor & $0-35$ & 18 & $95 \%$ \\
\hline \multicolumn{3}{|c|}{ TOTAL } & 19 & $100 \%$ \\
\hline
\end{tabular}


Table 4.2 above shows the rate percentage of score of Controlled class in pre test from 19 students, none of the students got Fair until Excellent score, there was 1 (5\%) student got Fairly Poor score, and there were 18 (95\%) students got Poor score.

\section{a. The Mean Score and Standard Deviation of Experimental Class and Controlled Class in Pre-test}

Before conducting the research, it was important to determine the mean score for both classes and the standard deviation to measure students' basic knowledge. Students' mean score for both classes and the standard deviation in the pretest were shown in the next page table.

Table 4.3 Mean Score and Standard Deviation of the students' pre-test result

\begin{tabular}{||c|c|c|}
\hline Class & Mean Score & Standard Deviation \\
\hline Experimental Class & 8.68 & 4.08 \\
\hline Controlled Class & 8.05 & 8.57 \\
\hline
\end{tabular}

The table above shows that, the mean score of Experimental class in pre-test is 8.68 and the standard deviation of Experimental class is 4.08. While the mean score of Controlled class in pre-test is 8.05 and its standard deviation is 8.57 . The table shows that the mean score of the students in the Experimental class was quite higher than in the Controlled class in which the gap between them is only 0.63 . The result of the mean score described that the difference of the students' basic knowledge was almost equal.

\section{b. The T-test and T-table of Experimental Class and Controlled Class in Pre-test}

The researcher conducted t-test and t-table to find out whether the result was significant or not and to be able to make sure whether the research could be continued or not. It can be seen in the following table:

Table 4.4 The significance difference of pre-test

\begin{tabular}{|c||c||c||}
\hline Classes & t-test & t-table \\
\hline \hline $\begin{array}{c}\text { Experimental Class \& } \\
\text { Controlled class }\end{array}$ & 0.29 & 2.021 \\
\hline
\end{tabular}

The table above shows that t-test of the pre-test between Experimental and Controlled class is 0.29 and the t-table is 2.021. Making a conclusion about students' score is by comparing the $\mathrm{t}$-test and the $\mathrm{t}$-table. When the result of the $\mathrm{t}$-test was smaller than the $\mathrm{t}$-table, it means that there was no significance among the result of the students' basic knowledge and it was appropriate for the research to be continued. The table above shows that there was no significance between students' score in the pre-test because the t-test was smaller than the t-table $(0.29<2.021)$ so the research could be continued. 
Dyan Elviyana Savitri \& Indah Fadhilah Rahman, The Use of Rap Music to Improve Students...

\section{The Result of Students' Post test in Experimental and Controlled Class}

The distribution of frequency and percentage of final score of students' vocabulary at the first grade at SMPN 2 Papalang, Mamuju Regency in post-test of Experimental class and Controlled class are shown in the following tables.

Table 4.5 The distribution of frequency and percentage score of Experimental class score in post-test

\begin{tabular}{|c|c|c|c|c|}
\hline No. & Classification & Score & Frequency & Percentage \\
\hline 1. & Excellent & $95-100$ & 0 & $0 \%$ \\
\hline 2. & Very Good & $85-94$ & 1 & $5 \%$ \\
\hline 3 & Good & $75-84$ & 1 & $5 \%$ \\
\hline 4. & Fairly Good & $65-74$ & 2 & $10 \%$ \\
\hline 5. & Fair & $55-64$ & 2 & $10 \%$ \\
\hline 6. & Fairly Poor & $45-54$ & 8 & $44 \%$ \\
\hline 7. & Poor & $0-44$ & 5 & $26 \%$ \\
\hline \multicolumn{5}{|c|}{ TOTAL } \\
\hline
\end{tabular}

The rate percentage of score of Experimental class in post test from 19 students as table 4.5 above shows that none students got Excellent score, there was 1 (5\%) student got Very Good score, 1 (5\%) student got Good score, 2 (10\%) students got Fairly Good score, $2(10 \%)$ students got Fair score, 8 (44\%) students got Fairly Poor score, and 5 (26\%) students got Poor score.

Table 4.6 The distribution of frequency and percentage score of Controlled class score in post-test

\begin{tabular}{|c|c|c|c|c|}
\hline \\
\hline No. & Classification & Score & Frequency & Percentage \\
\hline 1. & Excellent & $95-100$ & 0 & $0 \%$ \\
\hline 2. & Very Good & $85-94$ & 0 & $0 \%$ \\
\hline 3 & Good & $75-84$ & 0 & $0 \%$ \\
\hline 4. & Fairly Good & $65-74$ & 0 & $0 \%$ \\
\hline 5. & Fair & $55-64$ & 0 & $0 \%$ \\
\hline 6. & Fairly Poor & $45-54$ & 2 & $10 \%$ \\
\hline 7. & Poor & $0-44$ & 17 & $90 \%$ \\
\hline \multicolumn{3}{|c|}{ TOTAL } & 19 & $100 \%$ \\
\hline
\end{tabular}

The rate percentage of score of Controlled class in post-test from 19 students as table 4.6 above shows that none students got Fair score until Excellent score, there were $2(10 \%)$ students got Fairly Poor score, and 17 (90\%) students got Poor score.

Based on the result above, it can be conclude that the rate percentage in post-test for Experimental class was great than in rate percentage in Controlled class. Although for both of the class improved. But it can be seen in the table 4.5 and 4.6. In Experimental class only $5(26 \%)$ students got poor score, while in Controlled class there were $17(90 \%)$ students got poor score. 


\section{a. The Mean Score and Standard Deviation of Experimental Class and Controlled Class in Post-test}

The next page table presented the mean score and standard deviation of the Experimental class and Controlled class in the post-test.

Table 4.7 Mean Score and Standard Deviation of the students' post-test result

\begin{tabular}{||c|c|c|}
\hline Class & Mean Score & Standard Deviation \\
\hline Experimental Class & 48.89 & 18.07 \\
\hline Controlled Class & 16.63 & 11.41 \\
\hline
\end{tabular}

The table indicated the mean score of Experimental class in the Post-test is 48.89 and the standard deviation 18.07. While the mean score of the Controlled class is 16.63 and the standard deviation is 11.41 .

It can be concluded that the use of Rap Music is beneficial to improve the vocabulary mastery of the students' because the mean score of students' pos-test in Experimental group is higher than the mean score of students' post-test in the Controlled class.

\section{b. The T-test and T-table of Experimental Class and Controlled Class in Post-test}

The researcher conducted t-test and t-table to find out whether the result was significant or not and to know the significant score between experimental and controlled class in the post-test. The result of the t-test can be seen in table 4.7 as next page table.

Table 4.8 The significance difference of post-test

\begin{tabular}{|c||c||c||}
\hline Classes & t-test & t-table \\
\hline \hline Experimental Class \& Controlled class & 6.74 & 2.021 \\
\hline
\end{tabular}

Table 4.8 shows the result of test of significance testing. For the level of significance $(\alpha)$ 0, 05 and the degree of freedom $(\mathrm{df})\left(\mathrm{N}_{1}+\mathrm{N}_{2}\right)-2=(19+19)-2=36$, showed that the value of the t-test was higher than $\mathrm{t}$-table. The result of the test clearly showed that there was a significant difference between the students' score in the Experimental and Controlled class after the treatment of RapMusic. It indicated that the RapMusicis quite effective in improving students' vocabulary mastery. It means null hypothesis $\left(\mathrm{H}_{0}\right)$ was rejected and alternative hypothesis $\left(\mathrm{H}_{1}\right)$ was accepted because the $\mathrm{t}$-test is higher than $\mathrm{t}$-table $(6.74>2.021)$. Hence, the hypothesis of the research is accepted.

\section{B. Discussion}

Rap Musicis an appropriate technique applied in the classroom in teaching vocabulary. This technique is helpful to increase students' interest and enjoying in learning which makes them more involves in their vocabulary mastery. In this study, several things have been 
Dyan Elviyana Savitri \& Indah Fadhilah Rahman, The Use of Rap Music to Improve Students...

inferred logically. First, for both classes, they were inclined to have similar problems, when they were conducting a pre-test, they were difficult in wrote and understood the meaning of a sentence, and do not know the meaning of verbs. Most of them could not answer the test or did not answer the test. Second, for both classes, they were showed their big desire to start learning process, even they were not know what irregular verb is at all. Third, before applying Rap Music in Experimental class, all of the students were in the very lowest level; poor. Fourth, after applying the Rap Music, students in Experimental class showed their improvement, the students' competence was very difference. Most of them are in Fairly Good, Good, and Very good.

Analysis of the mean score gap in the post-test between the Experimental and controlled ensures if the technique used was effective. The mean score of the Experimental class was 48.89 and 16.63 for Controlled class. It means the gap of the students' score of the Experimental and Controlled class is 32.26. The explanation of the gap between the two classes indicates that the Experimental class shows high increasing than the Controlled class.

To sum up, based on the result of this study, which shows the students' scores were much higher after the treatment in Experimental class using Rap Music, the use of Rap Music for vocabulary teaching is surely beneficial to improve students' vocabulary mastery.

The finding above are in line with some theories. Medina (2002) agreed that we have good memory with music because all those repetitive words and rhythm stay in our head even after the English lesson. When we add rhythm and melody into language, it will help us to transfer words into long-term memory. Medina concluded that it is impossible to acquire language without memory.

According to Schoepp (2000), the repetitive nature of many rap songs can help English learners to get familiar with new words and phrases as they can rhyme and sing along, music also is a powerful medium to motivate students to learn a second or foreign language. Many rap songs, just like folk songs, follow a repeated verse and rhyme, and that makes them easy to follow, for teenagers, it is important to improve their listening and speaking skills, as well as their attention span and memory (Saricoban and Metin, 2000).

When students listen to songs and sing along, the experience is enjoyable and stressfree, it can help second language learners to acquire the language more naturally and effectively. If according to Abbott's (2002) theory, repetition can help build language and fluency, then rap songs can definitely help stimulate second language learning because of its repetitive format.

The result of the test in this study clearly showed that there was a significant difference between the students' score in the Experimental and Controlled class after the treatment of Rap Music. It indicated that the Rap Music is quite effective in improving students' vocabulary mastery. It means null hypothesis $\left(\mathrm{H}_{0}\right)$ was rejected and alternative hypothesis $\left(\mathrm{H}_{1}\right)$ was accepted because the $t$-test was higher than $t$-table $(6.74>2.021)$ or in the other words the 
value of the t-table was less than the value of $t$-test. It supported by Gay (2006: 346) who stated that if $\mathrm{T}$ table $\leq \mathrm{t}$ test means Effective, while if $\mathrm{T}$ table $\geq \mathrm{t}$ test means not effective. Hence, the hypothesis of the research is accepted.

\section{CONCLUSION}

Based on the findings the students' mastery in vocabulary improves to a greater extent through applying Rap Music in the first grade SMPN 2 Papalang, Mamuju regency. The total score of students in Experimental class in the pre-test was 165 and 153 for Controlled class. While, the mean score in pre-test for Experimental class was 8,68 and 8,05 for Controlled class. The total score of students in Experimental class in the post-test was 929 and 316 for Controlled class. In addition, the mean score in post-test for Experimental class was 48,89 and 16,63 for Controlled class. The data above shows that students' competence in Experimental class was higher than in Controlled class. The t-test for both classes in post-test was 6,74 compared to the t-table with 2.02. Since the score of t-test was larger than the score of t-table, null hypothesis $(\mathrm{H} 0)$ was rejected and alternative hypothesis (H1) was accepted. It means that the Rap Music which was applied in the Experimental class was effective to improve students' vocabulary mastery.

\section{SUGGESTIONS}

In relation to the conclusion above, the researcher proposes the following offers:

1. It suggested that the teacher could use the Rap Music as one of the technique in teaching and improve the students' vocabulary mastery especially in irregular verbs.

2. Implementing Rap Musicit's suitable in the beginner students as long as the music is played slowly and should be repeated until the students can speak it up fluently then sing together.

3. If the teacher wants to conduct the Rap Music as a teaching technique, it suggested that the teacher has to prepare the tools or media in teaching learning process such as laptop, projector, speaker, soundproof classroom, and electricity.

4. A teacher should teach the students with no force therefore the students can be more relax in learning and the transfer of knowledge can be faster.

5. The English teacher should be give rewards to the students that have better results in learning to motivate them so they will try their best in learning.

6. The English teacher should be more creative to choose media/method in teaching vocabulary, arrange the learning process, using unique media, creative in building the learning environment, and become the best facilitator in learning situation, so that the students will be more interested and motivated to study English.

7. The English teacher may apply this technique as a way to improve the students' vocabulary mastery, as a consideration that has been review before, if vocabulary as the 
Dyan Elviyana Savitri \& Indah Fadhilah Rahman, The Use of Rap Music to Improve Students...

foundation in every aspect four English skill. Thus the learner can be more exited in learning English.

\section{BIBLIOGRAPHY}

Abbott, M. Using music to promote L2 learning among adult learners. TESOL Journal , 2002. 11 (1), 10-17. Retrieved on May 28, 2015.

Arikunto, Suharsimi. Prosedur Penelitian: Suatu Pendekatan Praktik. Cet. 15: Jakarta: Rineka Cipta, 2013.

Barnhart, Cynthia A. The Facts on File Students' Dictionary of American English. Facts on File. 2008

Brandt, A., Gebrian, M., Slevc. R. L,. Music and early language acquisition.UK: Pascal Belin, University of Glasgow, 2012.

Burhayani. The effectiveness of teaching vocabulary through songs to second years students of Ikatan Keluarya Kesejabteraan Tentara (IKKT) Elementary School West Jakarta. Jakarta: Universitas Negeri Jakarta, 2013.

Burke, Lacie. Expert Tip: Leraning English by Listening to Music. 2014. From http://englishlive.ef.com/blog/expert-tip-learn-english-by-listening-to-music/.

Retrieved on May 12, 2016.

Fischler, Janelle. The Rap On Stress: Teaching Stress Patterns To English Language Learners Through Rap Music. Volume 26, 2009. Retrieved on May 28, 2015

Gay, L. R. Education Research: Competencies for analysis and Application. 2nd ed. Columbus, OH: Charles E. Merrill, 1981.

Gay, L. R. Education Research: Competencies for analysis and Application. 8th ed. United State: Earson Merrill Prenfile Hall. 2006.

Harisman, Muhammad. Developing the Second Year Students Vocabulary Through Listening to English Song at Madrasah Aliyah Syekh Yusuf Sungguminasa. Makassar. A thesis of UIN. 2014.

Hornby, A.S. Oxford University Learners Dictionary Current English Longman. University press. 1989.

Huy Le, M. The role of music in second language learning: A Vietnamese perspective. 2007. From http://www.englisclass.canalblog.com. Retrieved on May 28, 2015.

Idham, Afif M. Improving the Students'VocabularyMastery UsingJumbles Letter Games to the Second Year of SMP IMMIM PUTTA Makassar. Makassar. A thesis of UIN, 2011.

Ismayanti. Using Koosh Ball to Improve the English Vocabulary of the Second Year Students of MTS. Syech Yusuf Sungguminasa Gowa. Gowa. A thesis of UIN, 2010.

Ječmínková, Andrea. Music and Songs in Adult ESL Teaching. Czech Republik: Masaryk University, 2009.

Jyothirmaye, S. M. English Music:An effective tool to teach/learn English Language. India: JTELT. 2011. 
Li, Xiangming and Brand, Manny. Effectiveness of Music on Vocabulary Acquisition, Language Usage, and Meaning for Mainland Chinese ESL Learners. China: HongKong Baptist University.

Medina, S. L. Using music to enhance second language acquisition: From theory to practice. 2002. From ESL through Music: http://www.forefrontpublishers.com/ eslmusic/articles/06.htm. Retrieved on May 12, 2016.

Nunan, Language Teaching Methodology a Textbook for Teacher. New York: Precentice Hall International, 1991.

Nur, Muzakkir. Improving the students English vocabulary by Using Vocabulary Tree Chart at the second year of Madrasah Aliab Disamakan Pallattae Kab. Bone. 2011

Oxford, Learner's Pocket Dictionary. Oxford university press. 2000

Perry, Imani. Prophets of the Hood: Politics and Poetics in Hip Hop. Durham: Duke University Press, 2004.

Saricoban,A. \& Metin, E. Songs, Verse and Games for Teaching Grammar. 2000. The Internet TESL Journal. http://iteslj.org/Techniques/Saricoban-Songs.html. Retrieved on May 12, 2016.

Segal, Beth. Teaching English as a Second Language through Rap Music: A Curriculum for Secondary School Students. San Fransisco: University of San Francisco, 2014.

Schoepp, K. Reasons for Using Songs in the ESL/EFL Classroom. The Internet TESL Journal 7:2 (2001). http://iteslj.org/Articles/Schoepp-Songs.html. Retrieved on May 12, 2016.

Sugiyono, Metode Penelitian Pendidikan: Pendekatan Kuantitatif, Kualitatif, dan R\&D. Cet. 21: Bandung: Alfabeta, 2015.

Sukirman, The Ability of The Fifth Semester Students of English Language and Literature Department at Alauddin Islam State University Makassar in Analyzing Sentence in Reading Text Using Cooperative Learning. Makassar. A thesis of UIN, 2010.

Thornbury, Scot. How to Teach Vocabulary. Essex: Pearson Education Limited. 2004.

UK Essays. Rap to Teach English as Second Language English Language Essay. 2015. From https://www.ukessays.com/essays/english-language/rap-to-teach-english-as-secondlanguage-english-language-essay.php\#ixzz3dCNsvn25. Retrieved on May 12, 2016.

Zuhdy, A. I. Improving the Students' Vocabulary Mastery Using Jumbles Letter Games to the Second Year of SMP IMMIM PUTRA MAKASSAR. Makassar. A thesis of UIN, 2011.

Zahro, M. The use of song lyrics to improve students' vocabulary of verb. Semarang: IAIN Walisongo. 2010 


\section{THE LYRICS}

\section{STICK STUCK STUCK by Fluency MC}

The microphone I TAKE (took, taken).

You SHAKE (shook, shaken).

WAKE (woke, woken) to the style I'm creating.

THINK (thought, thought). SEEK (sought, sought).

listen to the lesson that I TEACH (taught, taught).

Don't SLEEP (slept, slept) I CREEP (crept, crept)

I SNEAK (snuck, snuck up) You LEAP (leapt, leapt)

I KEEP (kept, kept) having fun. I'm never BEAT (beat, beaten)

I WIN (won, won) DO (did, done) BEGIN (began, begun).

SHOOT (shot, shot). No, I don't own a gun. I LEAD (led, led)

so I can FEED (fed, fed) the knowledge you need,

straight to your head. When I BRING (brought, brought) it,

you CATCH (caught, caught) it. Sit back, relax.

Don't FIGHT (fought, fought) it.

Please don't FREEZE (froze, frozen) when I SPEAK (spoke, spoken)

It's real. You can feel I don't STEAL (stole, stolen)

I CHOOSE (chose, chosen) the very best rhymes and

WRITE (wrote, written) them into my lines and into your mind.

When we MEET (met, met) I'll BET (bet, bet)

I won't let you FORGET (forgot, forgotten). I GET (got, gotten)

every head nodding Don't think about stopping

just COME (came, come). This is hip hop. I don't SING (sang, sung).

I STING (stung, stung). I CLING (clung, clung).

On each and every word, you HANG (hung, hung).

It's not enough to DREAM (dreamt, dreamt)

you've got to SPEND (spent, spent) time on your goals.

Please LEND (lent, lent) me your ear.

Come near and I'll lay (laid, laid)

down this new sound that I MAKE (made, made).

I hope you don't say that you think it's junk.

I hope you don't think that I STINK (stank, stunk).

If you're thirsty for English, come DRINK (drank, drunk)

because I SINK (sank, sunk) all the competition 
when they HEAR (heard, heard)

that I GIVE (gave, given) encouragement

when I SPIT (spat, spat).

NeverQUIT (quit, quit); don't SIT (sat, sat)

Yeah, I like it like that. I'll even KNEEL (knelt, knelt)

and beg you to express what you FEEL (felt, felt)

I RISE (rose, risen) when I DRIVE (drove, driven)

through the beat; tap your feet as you RIDE (rode, ridden)

Those that HIDE (hid, hidden) I FIND (found, found)

If you FLEE (fled, fled) then I'll track you down Now you SEE (saw, seen) that I MEAN (meant, meant)

every word of the message that I SEND (sent, sent)

I SHOW (showed, shown) I can FLY (flew, flown)

Now you KNOW (knew, known) I SHINE (shone, shone)

I'll THROW (threw, thrown) you the ball. It's your turn

GROW (grew, grown) with the verbs that you've learned

grammar through lyrics I DRAW (drew, drawn)

Peace to ELLs, now I GO (went, gone) 